DOI: https://doi.org/10.24127/ajpm.v10i4.3550

\title{
ETNOMATEMATIKA DAN NILAI KARAKTER DALAM PERMAINAN TRADISIONAL KEBETUK
}

\author{
Yuliana Olga Siba Sabon ${ }^{1 *}$, Nur Hidayanto Pancoro Setyo Putro ${ }^{2}$, Abdul Rahim ${ }^{3}$ \\ $1^{*}, 2,3$ Unversitas Negeri Yogyakarta, Yogyakarta, Indonesia \\ "Coresponding author \\ E-mail: $\quad$ yuliana0032pasca.2020@student.uny.ac.id ${ }^{\left.1^{*}\right)}$ \\ nur_hidayant@uny.ac.id ${ }^{2)}$ \\ abdulrahim.2019@student.uny.ac.id ${ }^{3)}$
}

Received 10 February 2021; Received in revised form 23 November 2021; Accepted 13 December 2021

\begin{abstract}
Abstrak
Permainan tradisional harus dilestarikan agar tidak menghilang dari tengah masyarakat. Salah satu caranya yakni dengan menerapkan permainan tradisional dalam pembelajaran. Beberapa penelitian terdahulu juga telah mengimplementasikan beberapa jenis permainan tradisional di dalam pembelajaran. Namun dari penelitian-penelitian tersebut, masih banyak jenis permainan tradisional edukatif di nusantara yang belum dikembangkan dan diterapkan dalam pembelajaran. Salah satu contoh permainan tradisional yang belum terekspos adalah Kebetuk, sebuah permainan tradisional yang berasal dari daerah Nusa Tenggara Timur, khususnya Flores Timur. Tujuan penelitian ini adalah untuk mengetahui unsur unsur matematika serta nilai karakter yang terdapat dalam kebetuk. Penelitian ini dilakukan dengan menemukan konsep matematika di dalam budaya (permainan kebetuk) yang disebut sebagai etnomatematika. Penelitian ini termasuk penelitian kualitatif dengan menggunakan metode etnografi. Proses pengumpulan data dilakukan dengan cara observasi dan wawancara mendalam. Dari hasil penelitian diketahui unsur - unsur matematika dalam permainan kebetuk terdiri atas sifat - sifat operasi hitung bilangan bulat (komutatif, asosiatif, distributif penjumlahan), pola, kombinasi, permutasi dan peluang. Serta nilai-nilai karakter yang terkandung dalam kebetuk adalah musyawarah-mufakat, kedisiplinan, kejujuran, pantang menyerah, dan gotong-royong. Permainan Kebetuk ini dapat diterapkan dalam pembelajaran matematika.
\end{abstract}

Kata kunci: Etnomatematika; kebetuk; nilai karakter; permainan tradisional.

\begin{abstract}
To prevent the disappearance from society, they need to be preserved. One of the ways is by applying them in the learning process as has been implemented in several previous studies. However, from those studies, the researchers saw that many types of traditional games have still not been developed and applied in learning regardless of various types of educational traditional games. One example of a traditional game that has not been exposed is kebetuk, the one originating from the East Nusa Tenggara region, especially East Flores Regency. Therefore, the purpose of this research was to find out the mathematical elements and character values contained in Kebetuk. This research was conducted by discovering the concept of mathematics in culture (kebetuk game) which can be referred to as ethnomathematics. This research was qualitative research using the ethnographic method. The data collection process was carried out employing observation and in-depth interviews. From the results, it is known that the mathematical elements in the kebetuk game consist of the characteristics of the integer arithmetic operation principle (commutative, associative, distributive addition), pattern, combination, permutation, and probability. In addition, the character values contained the game are consensus, discipline, honesty, determination, and mutual cooperation. The kebetuk game can be applied in learning mathematics.
\end{abstract}

Keywords: character value; ethnomathematics; kebetuk; traditional game.

This is an open access article under the Creative Commons Attribution 4.0 International License 
DOI: https://doi.org/10.24127/ajpm.v10i4.3550

\section{PENDAHULUAN}

Permainan tradisional adalah perwujudan atau simbolisasi dari pengetahuan turun-temurun yang memiliki beragam fungsi dan peran. Selain itu, permainan tradisional juga merupakan hasil budaya yang memiliki manfaat yang besar bagi anak untuk mengekspresikan diri dalam fantasi, rekreasi, kreasi, olah raga, serta melatih untuk hidup bermasyarakat, mengembangkan keterampilan, serta prilaku sopan - santun (Andriani, 2012). Meskipun demikian permainan tradisional yang penuh dengan nilai nilai budaya, karakter bangsa, dan berbagai unsur yang bermanfaat ini, kini kian ditinggalkan (Nur, 2013; Royana, 2017).

Menurunnya animo permain tradisional disebabkan oleh munculnya berbagai permainan modern dengan berbagai fitur yang menarik, sehingga mengakibatkan aktivitas bermain permainan tradisional hampir tidak ditemukan lagi atau hampir punah. (Nur, 2013; Saputra \& Ekawati, 2017; Wulansari, 2017). Permainan tradisional ini sewaktu-waktu akan punah bila tidak dilestarikan, padahal permainan tradisional diketahui memiliki banyak potensi yang dapat dimanfaatkan.

Salah satu potensi yang dimiliki dalam permainan tradisional adalah memiliki muatan pembelajaran matematika. Hal ini telah dibuktikan oleh penelitian sebelumnya pada permainan dengklaq (Fauzi \& Lu'luilmaknun, 2019), nasi goreng kecap (Rosikhoh \& Abdussakir, 2020), congklak (Siregar et al., 2018), engklek (Aprilia et al., 2019), permainan kempreng (Susanti, 2020), kelereng (Febriyanti et al., 2019; Pratiwi \& Pujiastuti, 2020), gasing (Febriyanti et al., 2018) dan masih banyak lainnya.
Beberapa penelitian terdahulu telah mengimplementasikan beberapa jenis permainan tradisional di dalam pembelajaran matematika misalnya dengan menggunakan media congklak untuk meningkatkan kemampuan berhitung (Nataliya, 2015), penggunaan permainan kelereng dalam pembelajaran matematika (Febriyanti et al., 2019), mengaitkan permainan engklek dan gasing dengan materi matematika tentang bangun datar dan bangun ruang (Febriyanti et al., 2018). Hasil penelitian yang menggunakan permainan tradisional tersebut diketahui dapat meningkatkan prestasi belajar matematika, dan meningkatkan pemahaman konsep matematika.

Permainan tradisional telah terbukti sangat relevan bila digunakan dalam pembelajaran matematika. Namun demikian, masih banyak jenis permainan tradisional di nusantara yang belum dikembangkan dan diterapkan dalam pembelajaran. Padahal begitu banyak jenis permainan tradisional yang edukatif, yang dapat diaplikasikan dalam pembelajaran untuk meningkatkan efektifitas pembelajaran, mengembangkan karakter dan juga menjawab tuntutan terhadap pengembangan pembelajaran yang kreatif, pembelajaran yang menerapkan literasi budaya, agar kekayaan budaya kita tidak tergerus oleh zaman.

Salah satu contoh permainan tradisional yang belum terekspos adalah Kebetuk. Kebetuk merupakan salah satu permainan tradisional yang berasal dari daerah Nusa Tenggara Timur, khususnya masyarakat Flores Timur. Permainan kebetuk dapat dimainkan oleh dua orang anak dan dapat pula dimainkan secara berkelompok (lebih dari 2 anak ). Permainan kebetuk menggunakan alat berupa bola kecil dan beberapa kulit kerang / siput kecil/ 
DOI: https://doi.org/10.24127/ajpm.v10i4.3550

kulit kemiri yang jumlahnya disesuaikan dengan kesepakatan para pemain.

Pada penelitian terdahulu, belum ditemukan adanya konten pembelajaran matematika yang memanfaatkan permainan Kebetuk sebagai media pembelajaran. Oleh karena itu melalui penelitian ini dilakukan eksplorasi terhadap permainan kebetuk untuk menemukan potensi - potensi yang terdapat dalam permainan kebetuk yang dapat dielaborasi dan dikaitkan dalam pembelajaran matematika. Kegiatan mengaitkan permainan tradisional yang merupakan representasi budaya dengan matematika, atau mengkaji matematika di dalam budaya dapat disebut sebagai etnomatematika. Etnomatematika merupakan sebuah pendekatan dalam pembelajaran matematika berbasis budaya lokal(Marsigit et al., 2019). Dengan menerapkan permainan tradisional dalam pembelajaran matematika, kita tidak hanya melestarikan warisan budaya tetapi juga memanfaatkan budaya yang dimiliki untuk menumbuhkan dan menguatkan karakter anak (Lacksana, 2017; Nur, 2013; Witasari \& Wiyani, 2020), serta menciptakan sebuah pembelajaran yang aktif dan kreatif. Sebuah pembelajaran dengan melibatkan anak-anak dalam sebuah aktivitas yang menyenangkan, sehingga matematika yang dianggap sebagai sebuah pelajaran yang sulit, formal dan kaku dapat dengan gembira dipelajari sebagai sebuah aktivitas yang menyenangkan (Febriyanti et al., 2019)

Berdasarkan uraian tersebut, permasalahan yang dikaji dalam penelitian ini adalah bagaimana konsep etnomatematika dalam permainan tradisional Kebetuk. Apa sajakah nilai karakter yang terkandung dalam permainan Kebetuk. Tujuan dari penelitian ini adalah untuk menemukan konsep etnomatematika serta nilai karakter yang terkandung dalam permainan tradisional kebetuk.

\section{METODE PENELITIAN}

Penelitian ini merupakan penelitian etnografi dengan pendekatan kualitatif. Penelitian ini dilakukan di Desa Lewobunga, Kecamatan Adonara Timur, Kabupaten Flores Timur, Provinsi Nusa Tenggara Timur.

Penelitian dilakukan dengan mengamati atau mengobservasi sekelompok anak yang memainkan permainan kebetuk dan melakukan wawancara mendalam terhadap 4 pemain kebetuk serta 3 narasumber lainnya yang merupakan orang yang berpengalaman (gemar) bermain kebetuk pada masa kecilnya, untuk memperoleh informasi yang menyeluruh dan mendalam tentang kebetuk.

Instrumen dalam penelitian ini adalah peneliti sebagai instrumen utama dan beberapa instrumen pendukung berupa pedoman observasi dan pedoman wawancara. Teknik analisis data yang digunakan dalam penelitian ini adalah triangulasi teknik dan sumber (wawancara pemain, wawancara narasumber di luar pemain, dan observasi).

Proses analisis data dilakukan dengan menggunakan model kualitatif Bogdan dan Biklen yakni mengorganisir data, pemilahan menjadi satuan - satuan tertentu, sintesis, pelacakan pola, penemuan hal - hal penting, dan penentuan apa yang harus dikemukakan kepada orang lain. Analisis data dengan model Bogdan dan Biklen dapat dilakukan selama pengumpulan data dan setelah pengumpulan data (Sugiono, 2016).

Analisis data yang dilakukan selama pengumpulan data di lapangan 
adalah dengan mengamati proses permainan kebetuk untuk melacak pola permainan, menemukan nilai - nilai karakter yang terkandung dalam proses bermain kebetuk. Selain itu di dalam analisis data di lapangan diterapkan pula triangulasi teknik dan sumber untuk mengetahui keabsahan data.

Analisis data yang dilakukan setelah pengumpulan data adalah mengorganisir data tentang gambaran permainan kebetuk, aturan permainan kebetuk, dan teknik bermain kebetuk serta memeriksa data berdasarkan triangulasi yang telah dilakukan di lapangan, kemudian melakukan sintesis, pelacakan pola, dan menemukan hal hal penting untuk mengungkap unsur unsur matematika dalam permainan kebetuk. Hal ini dilakukan agar data dan hasil penelitian yang diperoleh akurat dan dapat diaplikasikan dalam pelajaran matematika di sekolah.

\section{HASIL DAN PEMBAHASAN}

\section{A. Permainan Kebetuk}

Permainan kebetuk merupakan sebuah permainan tradisional yang berasal dari masyarakat Flores Timur. Permainan kebetuk diyakini keberdaannya telah ada sejak tahun 1950an. Tidak diketahui dari mana asalnya dan siapa yang memainkan terlebih dahulu. Berdasarkan narasumber yang lahir tahun 1960an, pada masa kecilnya mereka sudah memainkan permainan kebetuk dan permainan kebetuk diyakini telah ada jauh sebelumnya. Permainan ini diwariskan secara turun temurun melalui penuturan dan tindakan (bermain kebetuk itu sendiri).

Permainan kebetuk dapat dimainkan oleh dua orang anak atau lebih secara individual maupun berkelompok. Permainan ini dimainkan dengan menggunakan alat berupa sebuah bola kecil (bola pimpong, kelereng, atau bola tenis) dan beberapa kulit kemiri atau kulit siput yang disesuaikan dengan kesepakatan para pemain. Permainan ini menuntut ketangkasan atau kelincahan para pemainnya. Pemain yang mengumpulkan poin terbanyak dalam menyelesaikan satu set rangkaian permainan kebetuk dinyatakan sebagai pemenang.

Sebelum memainkan kebetuk, para pemain membuat kesepakatan bersama atau yang disebut sebagai aturan main kebetuk. Aturan main kebetuk tersebut dapat berupa:

1) Banyak alat permainan kebetuk; dalam hal ini adalah jumlah kulit kemiri atau siput yang digunakan. Banyaknya jumlah kulit kemiri atau siput yang digunakan disesuaikan dengan kesanggupan dan kesepakatan para pemain. (Misalnya: 4 kulit kemiri/ 4 siput, 5, 6, dst.).

2) Berapa siput/ kulit kemiri yang ditutup atau dibuka dalam sekali lemparan; Misalnya (1 lemparan 3 kulit kemiri yang dibuka/ ditutup, dst)

3) Bola yang dilemparkan hanya bisa memantul 1 kali.

4) Bola harus ditangkap oleh pemain dengan tepat dan bola tersebut tidak boleh terjatuh dari tangan pemain.

5) Tidak boleh ada pergantian tangan pada saat melempar dan menangkap bola.

6) Dalam proses bermain kebetuk ada istilah yang disebut merambang yakni proses mengambil siput/ kulit kemiri dalam sekali lemparan bola. Merambang harus dilakukan dengan tepat sesuai dengan tahap permainan kebetuk. 
7) Terjadi pertukaran pemain apa bila: tidak dapat menutup / membuka siput sesuai kesepakatan, bola memantul lebih dari 1 kali di permukaan lantai, bola tidak dapat ditangkap atau terjatuh dari tangan pemain, pemain tidak dapat mengambil atau mengumpulkan siput/kulit kemiri dalam satu kali gerakan atau terjadi kesalahan merambang.

8) Pada saat terjadi pertukaran pemain, pemain sebelumnya tidak boleh melupakan tahap terakhir yang dimainkannya. Apabila pemain melupakan atau salah memainan permainan kebetuk yakni tidak sesuai dengan tahap terakhir permainannya maka terjadi pertukaran pemain ke pemain selanjutnya.

9) Pemain mendapatkan 1 poin setiap kali menyelesaikan 1 set atau 1 rangkaian permainan kebetuk secara menyeluruh.

Di dalam permainan kebetuk terdapat tahapan bermain yang unik. Permainan kebetuk dimainkan dalam 3 tahapan yakni tahap biasa, tahap buka, dan tahap tutup.

Tahap biasa merupakan tahap yang paling awal dalam permainan. Tahap biasa atau tahap awal ini dilakukan dengan tidak membedakan siput / kulit kemiri yang terbuka maupun tertutup. Tahap biasa dibagi lagi menjadi beberapa kegiatan yang disesuaikan dengan jumlah siput / kulit kemiri. Tahap biasa dilakukan sebagai berikut: Satu biasa (1 biasa): siput/ kulit kemiri diambil satu persatu dalam sekali lemparan bola. Dua biasa (2 biasa): siput/ kulit kemiri diambil dua - dua dalam sekali lemparan bola hingga terambil semuanya. Misalnya siput/ kulit kemiri yang digunakan berjumlah
5, maka dapat dilakukan sebagai berikut: siput/kulit kemiri diambil duadua dan pada bagian akhirnya adalah satu siput/kemiri yang yang tersisa. Semua teknik pengambilan siput/kulit kemiri ini dilakukan dalam sekali lemparan bola. Tiga biasa (3 biasa): siput / kulit kemri diambil tiga - tiga dalam sekali lemparan bola hingga terambil seluruhnya. Misalkan siput/ kulit kemiri yang digunakan berjumlah 5; maka dapat dilakukan dengan cara siput/ kulit kemiri diambil tiga, kemudian pada bagian akhirnya adalah dua kemiri yang tersisa, dan seterusnya. Hal yang sama dilakukan hingga ( $n$ biasa). $n$ adalah jumlah siput/ kulit kemiri secara keseluruhan. Misalnya jumlah siput/ kulit kemiri secara keseluruhan ada 5 maka tahap biasa dilakukan hingga lima biasa. pada tahap lima biasa, seluruh siput/kulit kemiri diambil semuanya dalam sekali lemparan bola.

Setelah menyelesaikan tahap biasa, tahap berikutnya adalah tahap buka. Pada tahap buka permainan dilakukan dengan memperhatikan siput/kulit kemiri harus dalam posisi terbuka. Jika ada siput/kemiri dalam keadaan tertutup maka hal yang pertama dilakukan adalah membuka siput/kulit kemiri yang tertutup terlebih dahulu. Membuka siput/ kulit kemiri dilakukan dengan memperhatikan aturan permainan kebetuk. Jika telah disepakati pada bagian awal untuk buka/tutup 5 dalam sekali lemparan bola maka hal tersebut harus dilakukan. Misalkan pada tahap buka, kelima siput/ kulit kemiri dalam posisi tertutup, maka pemain terlebih dahulu membuka kelima siput/kulit kemiri tersebut dalam sekali lemparan bola. Setelah memastikan semua siput/kulit kemiri telah terbuka, maka pemain dapat melanjutkan ke proses merambang. Proses merambang 
dilakukan dengan cara sebagai berikut: Satu buka: mengambil satu per satu siput / kulit kemiri yang sudah terbuka dalam sekali lemparan bola. Dua buka: mengambil dua siput / kulit kemiri yang sudah terbuka dalam sekali lemparan bola. Tiga buka: mengambil tiga siput/ kulit kemiri dalam sekali lemparan bola; setiap rambang berisi 3 siput/kulit kemiri. Jika siput atau kulit kemiri tersebut berjumlah 5 maka pada bagian terakhir yang dirambang adalah dua siput/kulit kemiri. Hal ini dilakukan seterusnya hingga tahap (n buka). n adalah jumlah siput/kulit kemiri secara keseluruhan.

Tahap terakhir dalam permainan kebetuk adalah tahap tutup. Tahap ini dapat dimasuki apabila pemain telah melewati tahap biasa dan tahap buka secara berurutan. Tahap tutup dilakukan dengan memperhatikan posisi siput/kulit kemiri yang tertutup. Jika ada kulit kemiri yang masih terbuka maka harus dilakukan penutupan terhadap siput/kulit kemiri tersebut terlebih dahulu. Penutupan siput/ kulit kemiri dilakukan dengan memperhatikan aturan permainan. Jika pada awalnya telah disepakati buka/tutup 5 dalam sekali lemparan bola. Maka hal tersebut harus dilakukan. Misalnya ada 5 siput/kulit kemiri yang terbuka maka kelima siput atau kulit kemiri tersebut ditutup dalam sekali lemparan bola. Atau misalkan dalam aturan telah ditetapkan tutup/buka 5 namun dalam permainan ada 4 siput/kulit kemiri yang terbuka, maka pemain menutup keempat siput/kulit kemiri tersebut secara bersamaan dalam sekali lemparan bola. Jika terjadi kesalahan penutupan yang mengakibatkan ada siput/kulit kemiri yang terbuka maka terjadi pertukaran pemain ke pemain berikutnya.
Setelah memastikan semua siput/kulit kemiri sudah dalam posisi tertutup maka tahap berikutnya adalah merambang. Proses merambang dilakukan sama seperti pada tahap biasa dan tahap buka, yakni: Satu tutup: mengambil satu per satu siput / kulit kemiri yang sudah tertutup dalam sekali lemparan bola. Dua tutup: mengambil masing - masing dua siput / kulit kemiri yang tertutup dalam sekali lemparan bola. Tiga tutup: mengambil masing masing tiga siput/ kulit kemiri yang telah tertutup dalam sekali lemparan bola, dan seterusnya. Hal ini dilakukan hingga ( $n$ tutup). $n$ adalah jumlah siput/kulit kemiri secara keseluruhan. Misalkan ada 5 siput/ kulit kemiri yang dimainkan maka pada tahap paling akhir yakni 5 tutup, pemain harus dapat mengambil semua siput/ kulit kemiri serta menangkap bola dalam sekali gerakan dengan menggunakan tangan yang sama.

Satu set siklus permainan kebetuk disajikan pada Gambar 1.

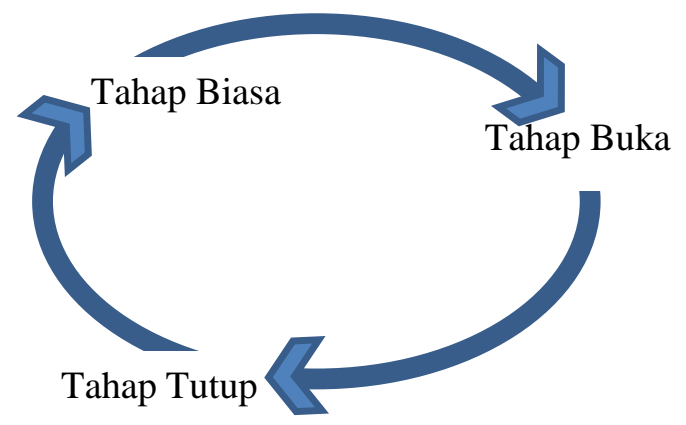

Gambar 1. Siklus Permainan Kebetuk

Jika pemain berhasil meyelelesaikan seluruh tahapan pada gambar 1, maka pemain berhasil mengumpulkan 1 poin. Kemudian permainan dilanjutkan lagi dari tahap biasa dan seterusnya. 
B. Unsur - unsur Matematika dalam Kebetuk

Berdasarkan hasil penelitian terhadap permainan tradisional kebetuk, diketahui bahwa kebetuk juga mengandung unsur - unsur matematika sebagaimana yang terdapat pada permainan tradisional dengklaq, congklak, engklek, nasi goring kecap, dan kempreng. Namun unsur - unsur matematika yang sama tersebut ditemukan dalam sajian yang berbeda karena perbedaan jenis permainan, pola permainan dan aturan permainan.

Berikut ini adalah unsur - unsur matematika dalam kebetuk adalah sebagai berikut:

1) Berlaku Sifat - sifat Operasi Hitung Bilangan Bulat

yakni sifat asosiatif, sifat komutatif dan distributif penjumlahan.

a) Sifat Komutatif.

Sifat komutatif atau sifat pertukaran dalam kebetuk berlaku untuk operasi hitung penjumlahan dan perkalian. Sifat komutatif penjumlahan dalam kebetuk terjadi pada tahap biasa, tahap buka, dan tahap tutup. Misalnya dalam permainan kebetuk yang menggunakan 5 kulit kemiri, pada tahap 2 biasa, 2 buka, dan 2 tutup serta tahap 3 biasa, 3 buka, dan 3 tutup dengan jumlah kulit kemiri yang sama, dapat berlaku sifat komutatif sebagai mana tampak pada Gambar 2.

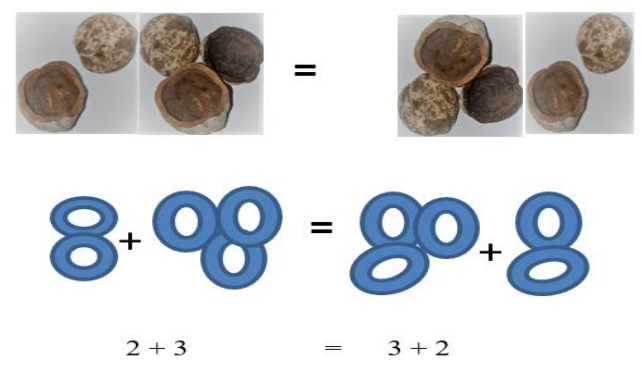

Gambar 2. Ilustrasi Sifat Komutatif Penjumlahan dalam permainan Kebetuk
Gambar 2 menampilkan proses pengambilan kulit kemiri pada tahap dua biasa dan tahap tiga biasa. Pada tahap dua biasa pengambilan pertama dilakukan pada dua kulit kemiri kemudian disusul dengan mengambil tiga kulit kemiri. Sedangkan pada tahap tiga biasa pengambilan pertama dilakukan pada tiga kulit kemiri kemudian disusul dua kulit kemiri. Jika 2 kulit kemiri disimbolkan $a$ dan 3 kulit kemiri disimbolkan $b$ maka berlaku:

$$
a+b=b+a
$$

persamaan (1) merupakan persamaan umum yang berlaku dalam operasi penjumlahan bilangan bulat atau disebut sifat komutatif penjumlahan bilangan bulat. Sedangkan sifat komutatif perkalian yang ditemukan dalam kebetuk sebagai berikut :

Pada permainan kebetuk yang menggunakan 6 kulit kemiri. Pada tahap tiga biasa, proses pengambilan kulit kemiri dilakukan sebanyak 2 kali dalam sekali lemparan bola. Jumlah tiap pengambilan dalam sekali lemparan bola adalah 3 (tahap 3 biasa/ 3buka / 3 tutup). Sedangkan pada tahap 2 biasal $2 b u k a$ / 2 tutup pengambilan kulit kemiri dilakukan sebanyak 3 kali dengan jumlah setiap pengambilan adalah 2 kulit kemiri. Proses ini tampak dalam ilustrasi pada gambar 3 .

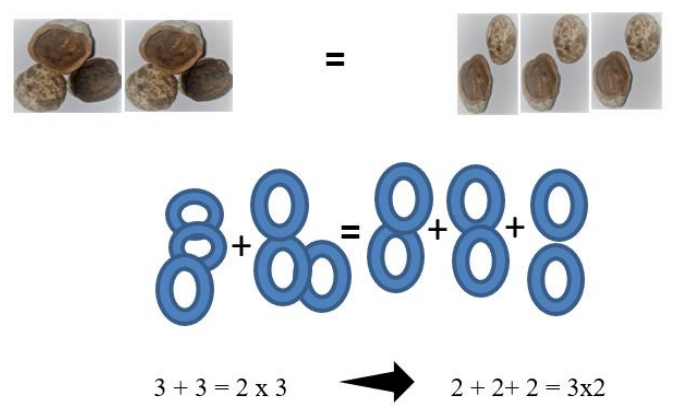

Gambar 3. Ilustrasi Sifat Komutatif Perkalian dalam Permainan Kebetuk 
DOI: https://doi.org/10.24127/ajpm.v10i4.3550

Berdasarkan ilustrasi pada Gambar 3 dapat disimpulkan; jika $2=a$ dan $3=b$ maka berlaku:

$a \times b=b \times a$

Persamaan (2) merupakan persamaan umum yang berlaku dalam operasi perkalian bilangan bulat atau disebut sifat komutatif perkalian bilangan bulat.

b) Sifat Asosiatif

Sifat asosiatif atau pengelompokan yang ditemukan dalam permainan kebetuk adalah asosiatif penjumlahan. Berikut ini merupakan gambaran asosiatif penjumlahan yang ditemukan dalam permainan kebetuk:

Misalnya dalam permainan kebetuk terdapat 6 kulit kemiri yang digunakan. Pada tahap 2 biasa / 2 buka / 2 tutup proses pengambilan dapat dilakukan dengan cara: mengambil 2 kulit terlebih dahulu kemudian diikuti 3kulit kemiri dan satu kulit kemiri. Namun terkadang karena terburu - buru atau ingin menyelesaikan lebih cepat para pemain dapat mengambil 2 kulit kemiri terlebih dahulu kemudian diikuti 4 kulit kemiri secara bersamaan. 4 kulit kemiri tersebut merupakan gabungan dari 3 kulit kemiri dan 1 kulit kemiri, sebagaimana tampak dalam Gambar 4.
Berdasarkan ilustrasi pada gambar 4 dapat disimpulkan; jika $2=a$ dan $3=b$, dan $1=c$ maka berlaku: $a+b+c=a(b+c)$

Persamaan (3) merupakan persamaan umum yang berlaku dalam operasi penjumlahan bilangan bulat atau disebut sifat asosiatif penjumlahan bilangan bulat.

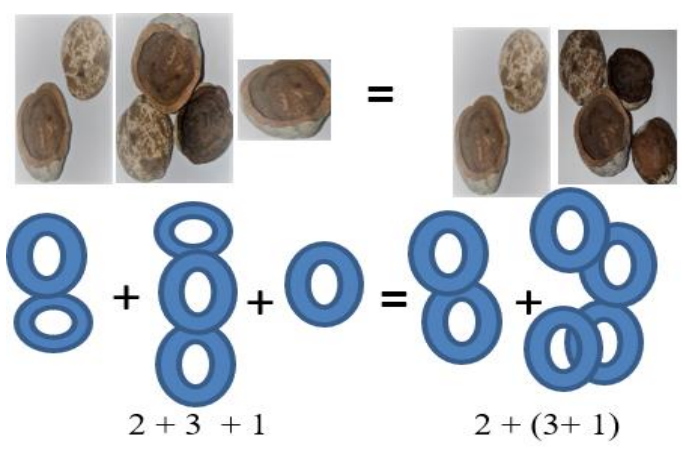

Gambar 4. Ilustrasi Sifat Asosiatif Penjumlahan dalam Permainan Kebetuk

c) Sifat Distributif

Sifat distributif atau penyebaran yang ditemukan di dalam permainan kebetuk adalah sebagai berikut : Misalkan permainan kebetuk menggunakan enam kulit kemiri, maka sifat distributif yang terlihat ketika proses pengambilan kulit kemiri dalam sekali lemparan bola dinyatakan dalam model matematika pada Tabel 1 .

Tabel 1. Ilustrasi Sifat Distributif Penjumlahan dalam Permainan Kebetuk

\section{Proses Pengambilan Kulit Kemiri Model Matematika}

\begin{tabular}{lll}
\hline $\begin{array}{l}\text { Ambil } 1: \\
\text { (tahap } 1 \text { biasa/ } 1 \text { buka/ } 1 \text { tutup) }\end{array}$ & $1 \times(6+0)$ & $=(1 \times 6)+(1 \times 0)$ \\
Ambil $2:($ tahap 2 biasa/ 2 buka/ 2 tutup) & $2 \times(1+2)=(2 \times 1)+(2 \times 2)$ \\
Ambil $3:$ (tahap 3 biasa/ 3 buka/ 3 tutup) & $3 \times(1+1)=(3 \times 1)+(3 \times 1)$
\end{tabular}


DOI: https://doi.org/10.24127/ajpm.v10i4.3550

Berdasarkan model matematika dalam ilustrasi yang disajikan pada Tabel 1, maka dapat dirumuskan sebagai berikut:

Jika $a$ adalah jumlah kulit kemiri yang pertama diambil, kemudian $b$ adalah jumlah kulit kemiri yang diambil kedua dan $c$ jumlah kulit kemiri yang diambil terakhir, maka berlaku:

$a \times(b+c)=(a \times b)+(a \times c)$.

Persamaan (4) merupakan persamaan umum yang berlaku dalam operasi hitung bilangan bulat atau disebut sifat distributif penjumlahan bilangan bulat.

Dengan demikian disimpulkan bahwa permainan kebetuk dapat diaplikasikan dalam pembelajaran matematika khususnya pada materi sifat - sifat operasi bilangan bulat. Hal ini sejalan dengan penelitian sebelumnya yang menggunakan permainan permainan tradisional congklak untuk mengenalkan konsep operasi hitung bilangan (Siregar et al., 2018; Susanti, 2020).

\section{2) Pola}

Di dalam permainan tradisional terdapat pola bilangan yang unik. Seperti dalam permainan nasi goreng kecap (Rosikhoh \& Abdussakir, 2020), permainan kebetuk pun mengandug pola bilangan dilihat dari pola pengambilan kulit kemiri dalam setiap satu kali lemparan bola.

Misalkan jumlah kulit kemiri yang dimainkan ada 5 maka proses pengambilan untuk setiap lemparan bola memiliki pola yang ditampilkan pada Tabel 2. Pola permainan kebetuk yang disajikan dalam tabel 2 dapat diringkas sebagai berikut: misalkan pengambilan ke-i $(\mathrm{i}=1,2,3, \ldots n)$ dengan $n$ adalah jumlah kulit kemiri/ siput secara keseluruhan, maka pola dalam permainan kebetuk dengan menggunakan 5 siput/kulit kemiri dapat dinyatakan sebagai berikut:

$$
\begin{aligned}
& i_{1}=1+1+1+1+1=1+(n-1) \ldots \\
& i_{2}=2+2+1=2+3=2+(n-2) \\
& i_{3}=3+2=3+(n-3) \ldots \ldots \ldots \ldots \\
& i_{4}=4+1=4+(n-4) \ldots \ldots \ldots \ldots \\
& i_{5}=5+0=5+(n-5) \ldots \ldots \ldots \ldots
\end{aligned}
$$

Berdasarkan persamaan (5) - (8) disimpulkan pola pengambilan siput/ kulit kemiri dalam permainan kebetuk ini adalah

Pengambilan ke- $i=i+(n-i)$...... (10)

\begin{tabular}{|c|c|}
\hline Pengambilan ke-i & Pola \\
\hline $\begin{array}{l}1 \text { (1 biasa/ 1buka/ } \\
1 \text { tutup): }\end{array}$ & $1+1+1+1+1$ \\
\hline $\begin{array}{l}2 \text { ( } 2 \text { biasa/ } 2 \text { buka / } \\
2 \text { tutup): }\end{array}$ & $2+2+1=2+3$ \\
\hline $\begin{array}{l}3 \text { ( } 3 \text { biasa / } 3 \\
\text { buka/ } 3 \text { tutup): }\end{array}$ & $3+2$ \\
\hline $\begin{array}{l}4 \text { (4 biasa / } 4 \\
\text { buka/ } 4 \text { tutup): }\end{array}$ & $4+1$ \\
\hline $\begin{array}{l}5 \text { (5 biasa / } 5 \\
\text { buka/ } 5 \text { tutup): }\end{array}$ & $5+0$ \\
\hline
\end{tabular}
Dengan $n=$ jumlah kulit kemiri yang digunakan secara keseluruhan.

Tabel 2. Pola permainan kebetuk menggunakan 5 kulit kemiri

\section{3) Permutasi dan Kombinasi}

Berdasarkan penelitian sebelumnya pada permainan engklek, konsep permutasi dapat ditemukan pada penentuan urutan permainan oleh para pemain (Aprilia et al., 2019). Di dalam permainan kebetuk urutan permainan di dasarkan pada urutan tempat duduk, sehingga posisi urutan yang diperebutkan adalah pemain pertama sehingga berlaku rumus permutasi sebagai berikut:

$$
P(n, 1)=\frac{n !}{(n-1) !} \ldots \ldots \ldots \text { (11) }
$$

Misalkan jumlah pemain dalam kebetuk adalah 4 pemain. Maka 
banyaknya pola urutan permainan adalah $P(4,1)=\frac{4 !}{(4-1) !}=4 \ldots \ldots \ldots .(12)$

Berbeda dengan pola urutan pemain, pada pola pengambilan kulit kemiri posisi kulit kemiri $\mathrm{AB}$ dianggap sama dengan BA sehingga konsep yang berlaku adalah kombinasi. Banyaknya cara mengambil kemiri merupakan representasi dari konsep kombinasi. ...

Ketika melakukan pengambilan kulit kemiri pada tahap biasa / buka / tutup, seorang pemain kebetuk telah menerapkan konsep kombinasi. Pada gambar 5, seorang anak sedang memainkan kebetuk dengan menggunakan 5 kulit kemiri, yang diberi simbol A, B, C, D dan E.

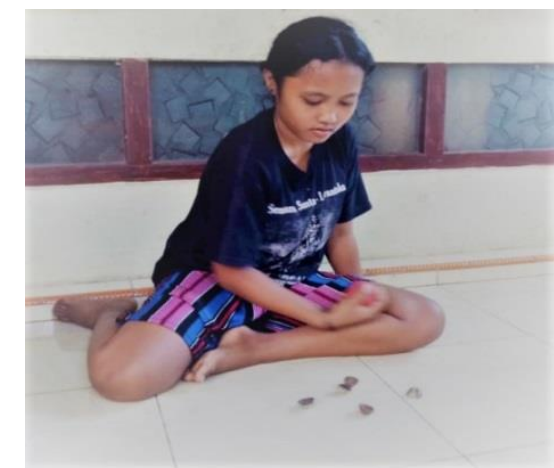

Gambar 5. Seorang anak bermain Kebetuk

Banyaknya cara yang dapat dilakukan anak tersebut untuk pengambilan $k$ kulit kemiri pertama ( $k$ $=1,2,3, . .5)$ dapat ditunjukan pada Tabel 3 .

Tabel 3. Konsep Kombinasi dalam Permainan Kebetuk

\begin{tabular}{ccc}
\hline $\begin{array}{c}\text { Pengambilan } \\
\boldsymbol{k} \text { kulit kemiri } \\
\text { pertama }\end{array}$ & Variasi cara pengambilan & $\begin{array}{c}\text { Banyaknya cara } \\
\text { yang dapat } \\
\text { dilakukan }\end{array}$ \\
\hline 1 & $\mathrm{~A}-\mathrm{B}-\mathrm{C}-\mathrm{D}-\mathrm{E}$ & 5 \\
2 & $\mathrm{AB}-\mathrm{AC}-\mathrm{AD}-\mathrm{AE}-\mathrm{BC}-\mathrm{BD}-\mathrm{BE}-\mathrm{CD}-\mathrm{CE}-$ & 10 \\
& $\mathrm{ED}$ & 10 \\
3 & $\mathrm{ACB}-\mathrm{ADE}-\mathrm{ABD}-\mathrm{ACE}-\mathrm{ACD}-\mathrm{BCD}-\mathrm{BDE}-$ & \\
4 & $\mathrm{BAE}-\mathrm{BCE}-\mathrm{CDE}$ \\
5 & $\mathrm{ABCD}-\mathrm{BCDE}-\mathrm{CDEA}-\mathrm{DEAB}-\mathrm{EABC}$ & 5 \\
& $\mathrm{ABCDE}$ & 1 \\
\hline
\end{tabular}

Banyaknya variasi cara mengambil $k$ kulit kemiri pertama ( $k=$ $1,2,3 \ldots$ dst) dapat dihitung dengan mengaplikasikan rumus kombinasi :

$$
{ }_{k}^{n} C=\frac{n !}{k !(n-k) !}
$$

dengan $\mathrm{n}$ adalah jumlah kulit kemiri yang digunakan secara keseluruhan dan $k$ adalah jumlah kulit kemiri pada pengambilan pertama.

Contoh menghitung banyaknya variasi cara mengambil 3 kulit kemiri pertama pada permainan kebetuk dengan menggunakan 5 kulit kemiri adalah sebagai berikut :

${ }_{3}^{5} C=\frac{5 !}{3 !(5-3) !}=\frac{5 !}{3 ! 2 !}=\frac{5 \times 4 \times 3 !}{3 ! 2 !}=10$

4) Peluang
Pada penelitian terdahulu, konsep peluang di dalam permainan ditemukan di dalam permainan dengklaq (Fauzi \& Lu'luilmaknun, 2019). Peluang pada permainan dengklaq dideskripsikan dengan peluang kemenangan yang didasarkan pada besarnya wilayah kekuasaan pemain, sedangkan pada permainan kebetuk, konsep peluang ditemukan pada harapan munculnya mata kulit kemiri tertutup atau pun terbuka (Gambar 3.a dan 3.b). 
DOI: https://doi.org/10.24127/ajpm.v10i4.3550

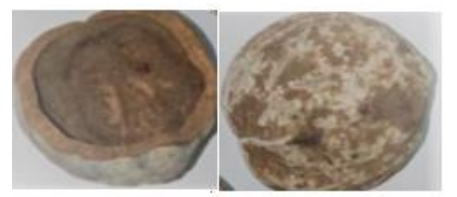

(a)

(b)

Gambar 3. (a) mata kulit kemiri terbuka,

(b) mata kulit kemiri tertutup

Misalkan peluang harapan seorang pemain kebetuk, bahwa dalam tahap tutup dari 5 kulit kemiri terdapat 3 kulit kemiri yang sudah tertutup. Peluang harapan pemain tersebut dapat dinyatakan sebagai berikut :

$0 \leq P(K) \leq 1$

Dengan $\mathrm{P}(\mathrm{K})$ adalah peluang kejadian. Secara matematis peluang harapan munculnya 3 kulit kemiri yang tertutup dari 5 kulit kemiri adalah

$P(K)=\frac{n(K)}{n(S)}, K \subset S$

Dengan $n(K)$ adalah banyak anggota kejadiaan dan $n(S)$ adalah jumlah sampel secara keseluruhan.

Sehingga,

$$
P(K)=\frac{3}{5}
$$

Jadi peluang munculnya 3 kulit kemiri yang tertutup dalam sekali lemparan bola adalah $\frac{3}{5}$ atau 0,6 .

Dengan demikian dapat disimpulkan bahwa dalam permainan tradisional kebetuk ditemukan unsur - unsur matematika yang dapat digunakan untuk menunjang proses pembelajaran di sekolah.

\section{Kebetuk Dan Nilai Karakter}

Permainan tradisional mengandung unsur pendidikan karakter yang sangat penting seperti nilai nasionalis, nilai kebersamaan, integritas, mandiri, gotong - royong, tanggung jawab, taat aturan, dan nilai - nilai luhur lainnya (Burhaein, 2017; Lacksana, 2017; Nur, 2013). Pada permainan tradisional kebetuk ditemukan pula berbagai nilai karakter yang terkandung di dalamnya, yakni:

a) Musyawarah - mufakat

Musyawarah mufakat dalam

kebetuk terjadi pada saat menentukan aturan permainan. Para pemain kebetuk akan menyepakati bersama peraturan yang dijadikan pedoman dalam bermain kebetuk.

b) Disiplin

Kedisiplinan dalam permainan kebetuk terlihat dalam cara para pemain menepati semua aturan permainan yang telah ditetapkan.

c) Kejujuran

Permainan kebetuk juga mengajarkan nilai kejujuran, di mana para pemain kebetuk mengakui kesalahannya dan pelanggarannya dalam bermain dan secara lapang memberikan kesempatan pada pemain berikutnya untuk bermain.

d) Pantang menyerah

Ketika bermain kebetuk parah pemain berjuang untuk menyelesaikan permainannya dan mencapai poin. Berbagai stratigi dilakukan misalnya melempar bola, kecepatan

mengumpulkan/mengambil kulit kemiri. Proses permainan kebetuk ini memperlihatkan karakter pantang menyerah.

e) Gotong royong

Permainan kebetuk juga mengandung nilai gotomg royong. Hal ini terlihat dalam permainan kebetuk secara berkelompok. Para anggota kelompok bersama berjual, melanjutkan permainan teman kelompoknya untuk mencapai target poin yang mereka harapkan.

Dengan demikian kebetuk dapat digunakan sebagai sarana untuk 
membentuk, menumbuhkan dan menguatkan karakter positif anak. Hal ini didukung oleh penelitian sebelumnya yang menunjukan bahwa penerapan permainan tradisional dalam pembelajaran terbukti dapat menumbuhkan dan menguatkan karakter positif (Lacksana, 2017). Selanjutnya penelitian dilakukan oleh (Witasari \& Wiyani, 2020) dalam upaya memanfaatkan permainan tradisional untuk membentuk karakter anak telah dilaksanakan secara sistematis dan hasilnya anak-anak mampu menampilkan karakter positif ketika melakukan kegiatan bermain permainan tradisional. Penelitian lainnya menyimpulkan bahwa permainan tradisional edukatif terbukti secara efektif dapat membantu meningkatkan karakter anak dan dapat membantu anak menguasai berbagai karakter positif yang dikembangkan dalam setiap permainan (Hapidin \& Yenina, 2016).

Penggunaan pendekatan pembelajaran berbasis karakter budaya berupa permainan tradisional memberikan pengaruh positif dalam penyelesaian masalah matematika dan memperkuat karakter positif anak (Cahyaningrum \& Sukestiyarno, 2016; Zayyadi et al., 2018). Penerapan permainan tradisional dalam pembelajaran matematika, tidak hanya meningkatkan kemampuan kognitif tetapi juga afektif anak. Hal ini mampu mendukung tercapainya pembelajaran matematika secara holistik dan terintegrasi dengan penguatan karekter positif anak.

\section{KESIMPULAN DAN SARAN}

Konsep etnomatematika (unsur matematika dalam budaya) yang ditemukan dalam permainan kebetuk adalah sifat operasi hitung bilangan bulat (yang terdiri dari : komutatif penjumlahan dan perkalian; asosiatif penjumlahan, distributif penjumlahan), permutasi, kombinasi, dan peluang. Nilai karakter yang ditemukan dalam permainan kebetuk adalah musyawarahmufakat, disiplin, kejujuran, pantangmenyerah, dan gotong royong.

Berdasarkan hasil penelitian ini maka permainan kebetuk dapat digunakan dalam pembelajaran untuk memahami konsep sifat - sifat operasi hitung bilangan bulat (komutatif, asosiatif, dan distributif penjumlahan), konsep kombinasi, permutasi dan peluang, agar pembelajaran matematika yang abstrak dapat dijadikan lebih konkrit, serta dapat digunakan untuk membentuk dan menguatkan karakter anak.

Pengembangan pembelajaran matematika berbasis permainan tradisional perlu ditingkatkan untuk mewujudkan pembelajaran yang holistik dan terintegrasi dengan penguatan karakter. Penelitian selanjutnya hendaknya menggali potensi dalam permainan tradisional yang belum tereksplor dan dapat menerapkan pembelajaran matematika berbasis permainan tradisional untuk mengetahui efektifitas permainan tradisonal dalam meningkatkan kemampuan kognitif maupun afektif bagi peserta didik.

\section{DAFTAR PUSTAKA}

Andriani, T. (2012). Permainan Tradisional Dalam Membentuk Karakter Anak Usia Dini. Jurnal Sosial Budaya.

Aprilia, E. D. A., Trapsilasiwi, D., \& Setiawan, T. B. (2019). Etnomatematika Pada Permainan Tradisional Engklek Beserta Alatnya Sebagai Bahan Ajar. Kadikma. 
DOI: https://doi.org/10.24127/ajpm.v10i4.3550

Burhaein, E. (2017). Aktivitas Permainan Tradisional Berbasis Neurosainslearning Sebagai Pendidikan Karakter Bagi Anak Tunalaras. Jurnal SPORTIF: Jurnal Penelitian Pembelajaran. https://doi.org/10.29407/js_unpgri. v3i1.580

Cahyaningrum, N., \& Sukestiyarno, Y. L. (2016). Pembelajaran React Berbantuan Modul Etnomatematika Mengembangkan Karakter Cinta Budaya Lokal dan Meningkatkan Kemampuan Pemecahan Masalah. Unnes Journal of Mathematics Education Research, 5(1), 50-59. https://journal.unnes.ac.id/sju/inde x.php/ujmer/article/view/12917

Fauzi, A., \& Lu'luilmaknun, U. (2019). Etnomatematika Pada Permainan Dengklaq Sebagai Media Pembelajaran Matematika. AKSIOMA: Jurnal Program Studi Pendidikan Matematika. https://doi.org/10.24127/ajpm.v8i3. 2303

Febriyanti, C., Kencanawaty, G., \& Irawan, A. (2019). Etnomatematika Permainan Kelereng. MaPan, 7(1), 32-40.

https://doi.org/10.24252/mapan.20 19v7n1a3

Febriyanti, C., Prasetya, R., \& Irawan, A. (2018). Etnomatematika Pada Permainan Tradisional Engklek Dan Gasing Khas Kebudayaan Sunda. Barekeng: Jurnal Ilmu Matematika Dan Terapan, 12(1), 1. https://doi.org/10.30598/vol12iss1 pp1-6ar358

Hapidin, H., \& Yenina, Y. (2016). Pengembangan Model Permainan Tradisional Dalam Membangun Karakter Anak Usia Dini. JPUD Jurnal Pendidikan Usia Dini. https://doi.org/10.21009/jpud.102.0 1

Lacksana, I. (2017). Kearifan Lokal Permainan Congklak Sebagai Penguatan Karakter Peserta Didik Melalui Layanan Bimbingan Konseling Di Sekolah. Satya Widya, 33(2), 109-116. https://doi.org/10.24246/j.sw.2017. v33.i2.p109-116

Marsigit, Condromukti, R., Setiana, D. S., \& Hardiarti, S. (2019). Pengembangan Pembelajaran Matematika Berbasis Etnomatematika. Journal of Chemical Information and Modeling.

Nataliya, P. (2015). Efektivitas Penggunaan Media Pembelajaran Permainan Tradisional Congklak Untuk Meningkatkan Kemampuan Berhitung Pada Siswa Sekolah Dasar. Jurnal Ilmiah Psikologi Terapan (JIPT). https://doi.org/10.22219/jipt.v3i2.3 536

Nur, H. (2013). Building children's character through traditional games. Junal Pendidikan Karakter.

Pratiwi, J. W., \& Pujiastuti, H. (2020). Eksplorasi Etnomatematika pada Permainan Tradisional Kelereng. Jurnal Pendidikan Matematika Raflesia.

Rosikhoh, D., \& Abdussakir, A. (2020). Pembelajaran Pola Bilangan melalui Permainan Tradisional Nasi Goreng Kecap. Jurnal Tadris Matematika.

https://doi.org/10.21274/jtm.2020. 3.1.43-54

Royana, I. F. (2017). Pelestarian Kebudayaan Nasional Melalui Permainan Tradisional dalam Pendidikan Jasmani. Seminar Nasional KeIndonesiaan II, 483493. http://eprints.upgris.ac.id/98/ 
Saputra, N. E., \& Ekawati, Y. N. (2017). Permainan Tradisional Meningkatkan Kemampuan Dasar Anak. Jurnal Psikologi Jambi.

Siregar, S. N., Solfitri, T., \& Roza, Y. (2018). Pengenalan Konsep Operasi Hitung Bilangan Melalui Permainan Congklak Dalam Pembelajaran Matematika. AlKhwarizmi: Jurnal Pendidikan Matematika Dan Ilmu Pengetahuan Alam. https://doi.org/10.24256/jpmipa.v2 i1.107

Sugiono. (2016). Metode Penelitian Kuantitatif, Kualitatif dan $R \& D$. Bandung: Alfabeta.

Susanti, E. (2020). Eksplorasi Etnomatematika Konsep Operasi Hitung dalam Permainan Tradisional Kempreng. Suska Journal of Mathematics Education.

Witasari, O., \& Wiyani, N. A. (2020). Permainan Tradisional untuk Membentuk Karakter Anak Usia Dini. JECED : Journal of Early Childhood Education and Development, 2(1), 52-63. https://doi.org/10.15642/jeced.v2i1 .567
Wulansari, B. Y. (2017). Pelestarian Seni Budaya Dan Permainan Tradisional Melalui Tema Kearifan Lokal Dalam Kurikulum Pendidikan Anak Usia Dini. Jurnal INDRIA (Jurnal Ilmiah Pendidikan Prasekolah Dan Sekolah Awal). https://doi.org/10.24269/jin.v2n1.2 017.pp1-11

Zayyadi, M., Hasanah, I., Surahmi, E., \& Matematika, P. P. (2018). Ethnomatematics Exploration in Traditional Games As A Form Of Student' Social Interaction. JIPM (Jurnal Ilmiah Pendidikan Matematika), 6(2), 125-132. https://doi.org/10.25273/JIPM.V6I 2.1826 